\title{
写真地質学的判読における基礎的要素の解析について
}

一逢坂山狭湓付近を例として——

河 原 紀 夫* $^{*}$
福 原

\section{On Analysis of Basic Elements for Photogeological Interpretation}

- Ōsakayama narrow and vicinity

\author{
by Michio Kawahara \\ Atsushi Fukuhara
}

\begin{abstract}
Abstruct
In recent years, the utility of aerial photographs have been recognized more universally, and aerial photograpos have come to be used widely for various photo-interpretations as well as for photogrammetry. We also were studying several photo-interpretations for sevral years and reporting the utility of its. This study have cohenrance with the photogeological studies which had reported by papers such as "Geological Study Using Photogeologic Interpretation. (part I, II)"

In this study, we examined basec elements (Tone, Texture, Moutain Shape, Valley Shape, Drainage, Vegetations, Soil, Erosin and Weathering, Landslide, Transported deposit.) for photogeological interpretation in vicinity of Osakayama, Shiga prefecture, where is underlain by Palaeozoic sediments.
\end{abstract}

A Summery of results of his study is as follows:

1) In consequence of photogeplogical interpretation, this area was divided into five lithologic units as follows:

I. Diluvium (Clay, Sand, Gravel, Lignite.)

II. Palaeozoic Group (Chert)

III. Palaeozoic (Alternation of chart, Shale and Sandstone)

IV. Igneous rock (Granite porphyry, Quartz porphyry)

V. Alluvium (Clay, Sand and Gravel)

However the formations which are narrow and have complex lithological components can not be definitely discrimitated by aerial photographs.

2) Large structual sets, such as faults and fractured zones, were mainly interpoetated on topographic feature. Small structural sets, such as joints and beding, were interpretated on vegetations and soil. These structures which were interpretated bo aerial photographs coincided with the structures mapped on the ground.

3) Photogeological survey which is based upon the scientific interpretation of features or aerial phoeographs in a very useful technical method inngeogical surveys.

まえがき 近年, 航空写真の有用性に対する認識が 高まり，その用途も従来の航空写真測量のみにとどま らず航空写真パンクロ，カラー，インフラレッド，力 ラーインフラレッドなど）そのものが広く利用される ようになった。とくに航空写真の判読（photo-interprctation）は, 地質学地質・地質構造の判読, 地过り,
崩壊の判読，流出土砂の判読など)，林学樹種の判定， 材種量の測定など）の分野を初めとして，土木工学 （交通流の解析，道路路面の判読，工事設計計画のため の判読，都市・公園計画のための判読など)，地理学 積雪の判読・測定，雪崩の判読，地形の判読，土地利 用の判読，洪水・地震などの災害の判読，流水・水質 の判読・測定など），気象学（煙・スモッグの判読な ど), 考古学（遺跡の判読など）, 海岸工学（流砂・漂 


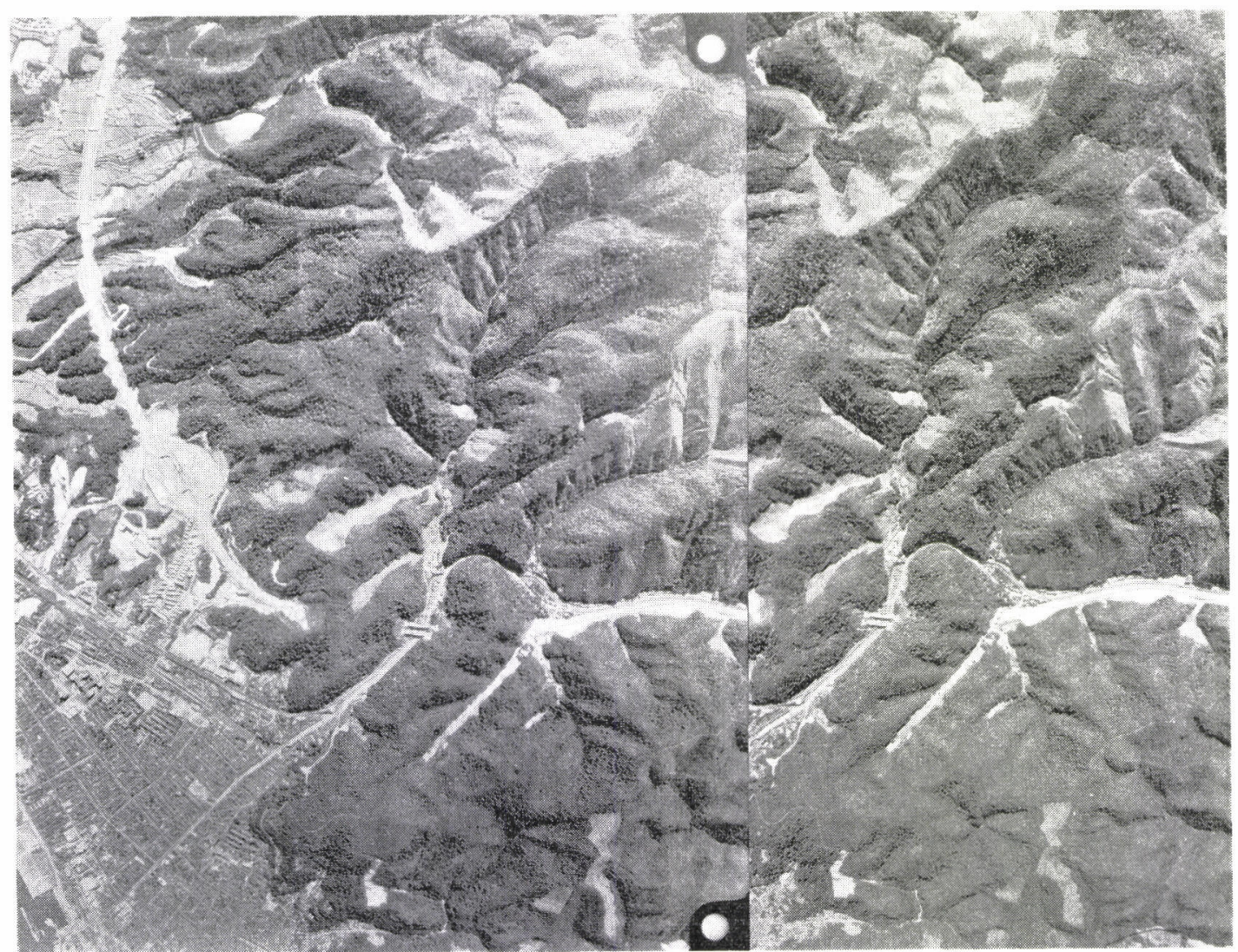

Fig. 1 Stereos copic pair of Osakayamama area. (逢坂山付近の立体航空写真)

砂の判読, 津波の判読など), 軍事目的のための判読, その他の非常に広い分野で実施されてきている。我及 もまた過去数年来これらの判読について研究し，航空 实真の判読が非常に有效であることを報告してきた。 さらに，その成果は各種の土木工事を初めとする種々 の实作業面に広く応用されている。

この論文は, すたに報告した“航空写真を利用した 地懫調査, そのI, そのII 在含む一連の写真地質学的 な判読の研究と一貫するものである。ここでは, その 一例として滋賀紧逢坟山狭险付近をとり上げてハンク 口航空写真上における写真地質学的判読のための基礎 的要素の判読・解析について述べ。

\section{I 写真地犋学的判読の概要}

一般に航空写真の判読は, Photo reading $\rightarrow$ Photo analysis $\rightarrow$ Photo interpretation の 3 段階をへて実施さ れ, 目的に応じて幾つかの基礎的要素が判読・解析さ れる。

写真地質学の判読・解析は Lueder およびVandat などによれば Table 1 に示したようなプロセスで実 施される。第一次写真地質学的判読 (First photogeological interpretatiin) の段階では, 一般に（1）色調,
（2）きめ, (3) 山形, (4) 谷形, (5) 水系, (6) 植生, （7）土壊，（8）侵蝕・風化の状態，（9）地过り地・崩 壊地, (10) 現世堆積物, (11) Photogeological iineament などの主要な基醍的要素が判読・解析され， そ の結果老総合的に検封し岩層および地質構造が判定さ れる。とくに断層, 破砕带, 節理, 層理などの地質構 造は, 地形, 岩層, 植生, 土壞などの上に現われる Photogeological lineament の判読・解析結果加判定 される。

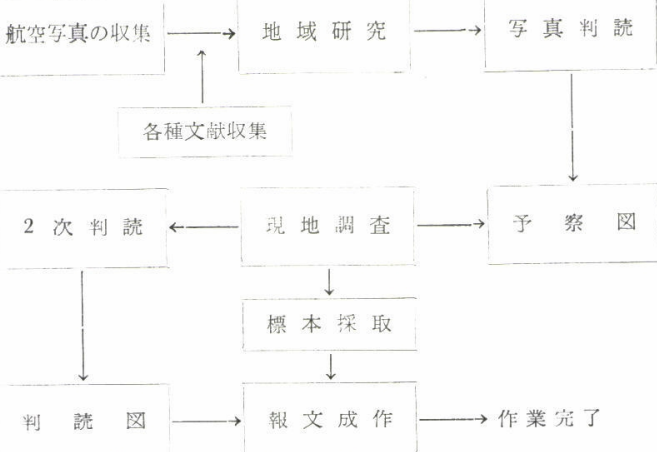

表-1 冥判読の一般的作業工程

Table 1. Flow chert of general steps for photogeological interpretation. 


\section{II 逢坂山狭险付近の写真地質学的判読}

この判読は，滋賀県大津市膳所町から京都府山科市 音羽町に至る逢坂山狭险沿い面積約 $18 \mathrm{~km}^{2}$ の地域で 行ったものである。航空写真は, 撮影高度 $2,430 \mathrm{~m}$, 縮尺 1/15,200 のハンンクロ航空写真 Fig. 1 を使用し, 1 部 2 倍に引き伸して判読した。

\section{II-1 地形 (Topographic feature) の判読}

II-1-1 水系㧍よび谷形 (Drainage and valley shape）の判読

水系模様は一般に地表下の地層の岩石学的性質及び 地質構造に規制されるところが大きく写真地質学的判 読に当っては極めて重要な要素である。水系の発達状 態抢よびパターンは, Fig. 2 に示した水系図から直接 読みとることがだきるこ れらから, その地形も加味 して，この地域を漸定的に $\mathrm{A}, \mathrm{B}, \mathrm{C}, \mathrm{D}, \mathrm{E}, \mathrm{F}$ の 6 つ の地区に区分し, Table 2 に示した水系密度 (単位面 積当りの水系の長さ）およ び水系頻度（単位面積当り の水系の数）を算定すると ともに Fig. 3, Fig. 4 に示 した水系等密度線図抢よび
水系等頻度線図を作成し定量的に解析した。さらにそ の方向と数を Fig. 5, 6, Fig. 7, Fig. 8 のダイアグラ ムに示し地質構造との関係を考察した。

これもともに谷の形態抢よび谷底堆積物の状態も加 えて判読し構成岩石の風化侵蝕に対する抵抗性を判定 した。

以上の諸要素の判読, 解析の結果からつぎのような 解釈を行った。

1）水系の発達状態およびハターンから，この地域は $\mathrm{A} \sim \mathrm{F}$ の 6 地区に区分でき，打の打のつぎのよう な特徴がみられる。

A地区：小さく曲流する支流の少ない水系が平行状 に発達する。

B地区：直角に屈曲するが格子状に発達する。

\begin{tabular}{|c|c|c|c|c|c|}
\hline Area & Number & Length & Square & Frequency & Dencity \\
\hline A & 44 & 8.1 & 2.45 & 18.0 & 3.3 \\
\hline B & 405 & 48.6 & 4.40 & 92.0 & 11.0 \\
\hline C & 629 & 84.2 & 5.09 & 123.6 & 16.5 \\
\hline D & 184 & 22.6 & 1.39 & 132.4 & 16.3 \\
\hline E & 20 & 3.4 & 0.91 & 22.0 & 3.7 \\
\hline F & 10 & 2.1 & 0.17 & 58.8 & 12.4 \\
\hline
\end{tabular}

Table 2 Drainage dencity and frequency. (水系密度及び水系頻度)

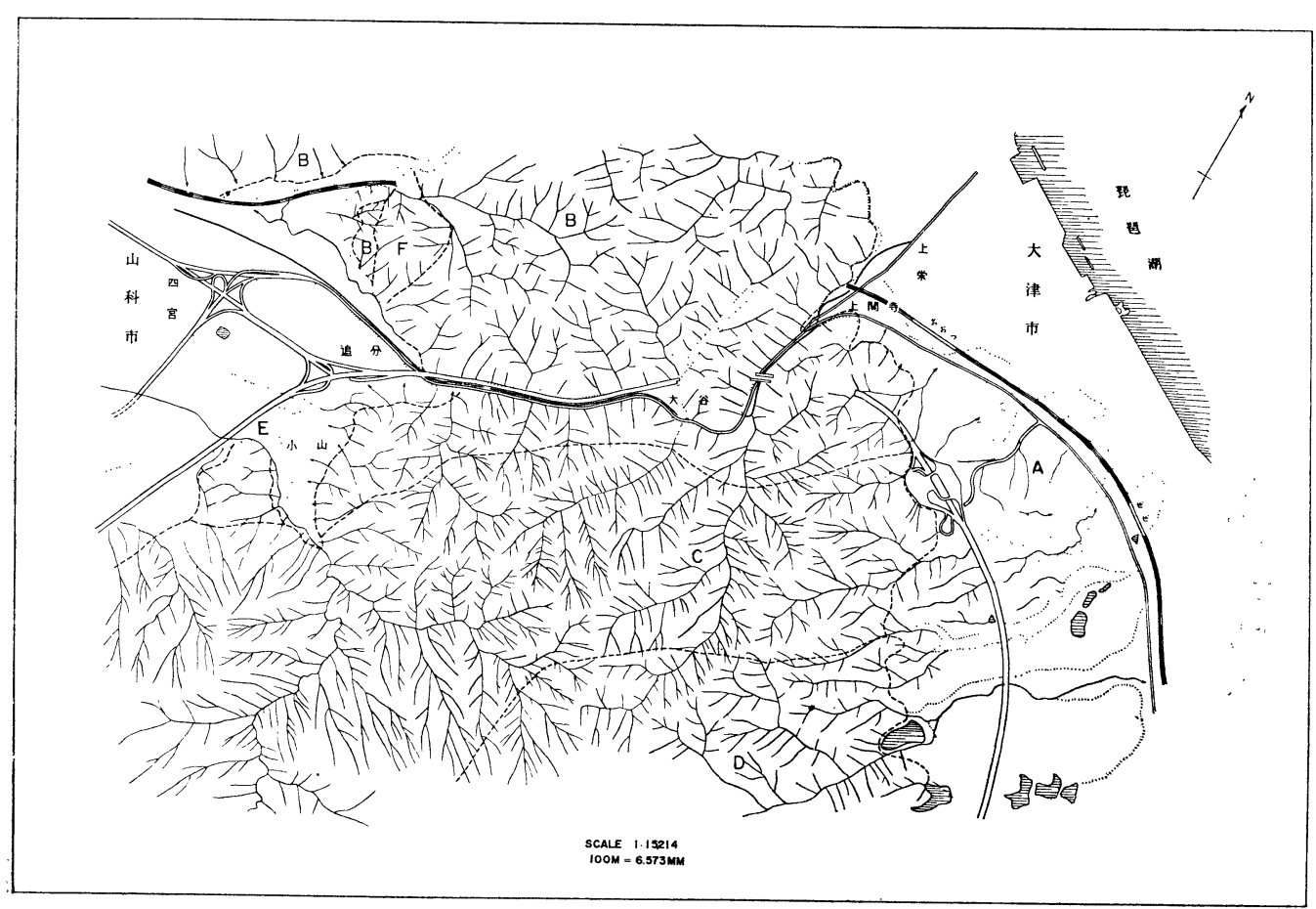

Fig. 2 Drrinage map of Ofakayama area. 


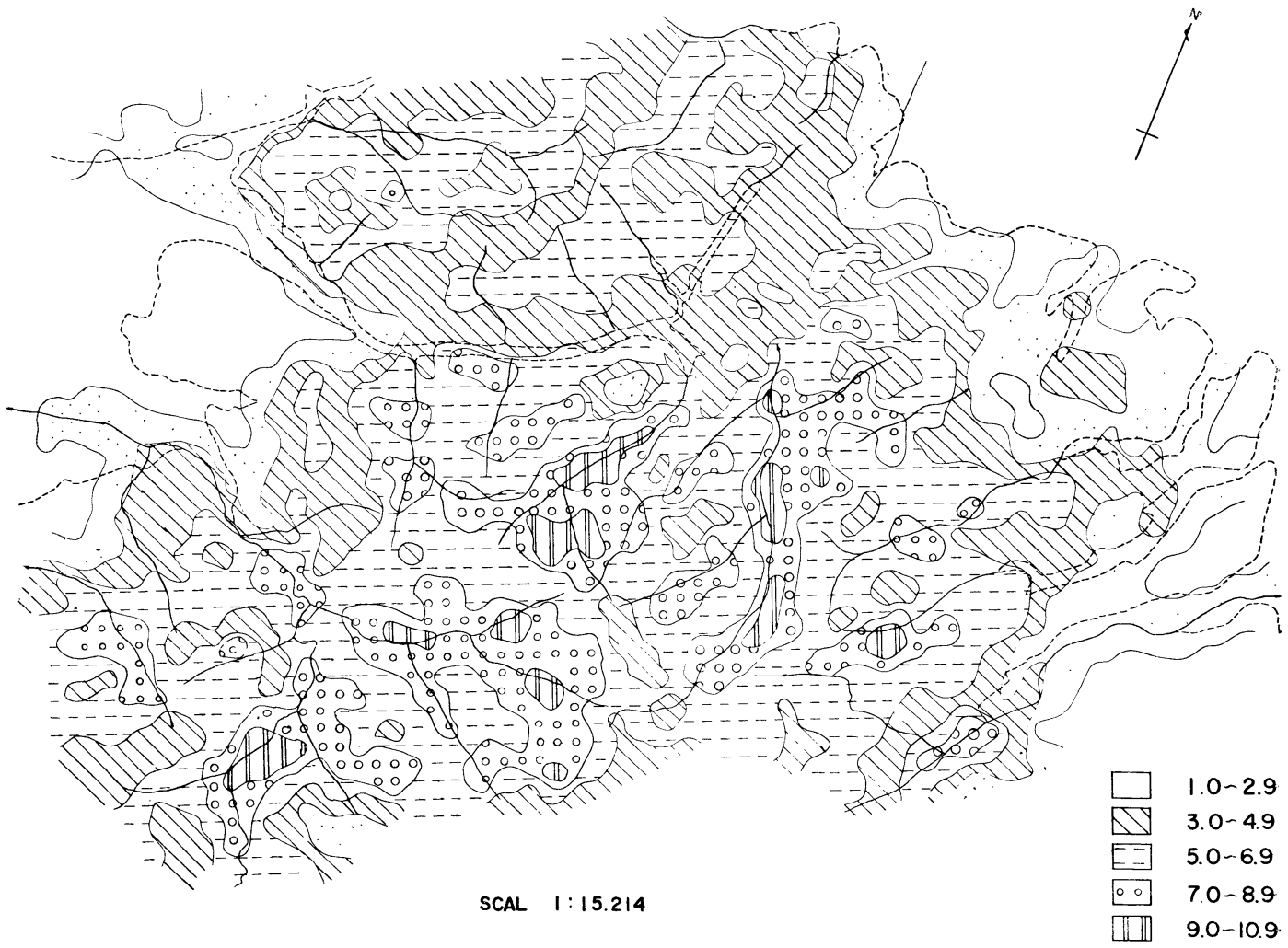

Fig. 3 Map of similar areas of drainage dencity.

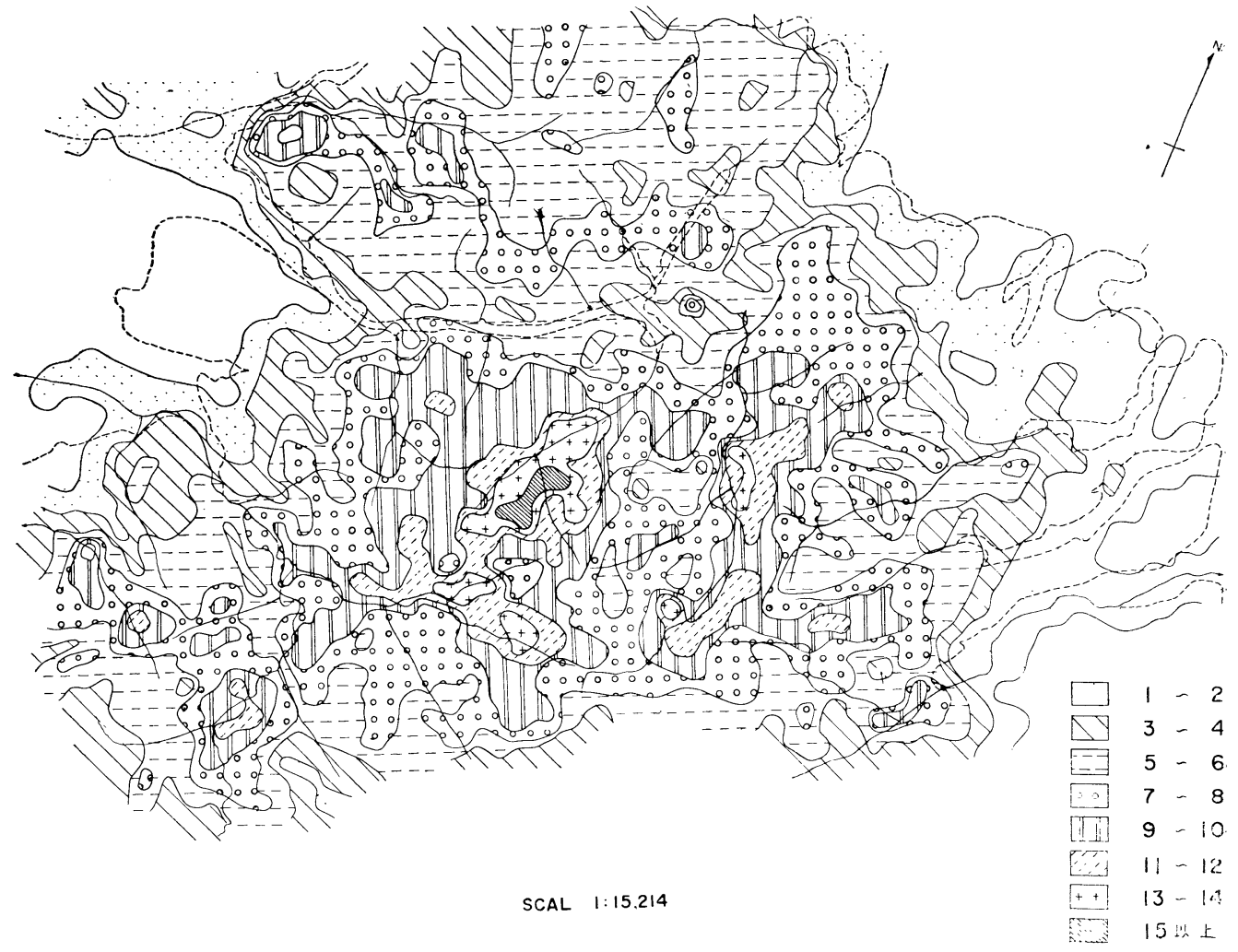

Fig. 4 Map of similar areas of drainage frequency. 


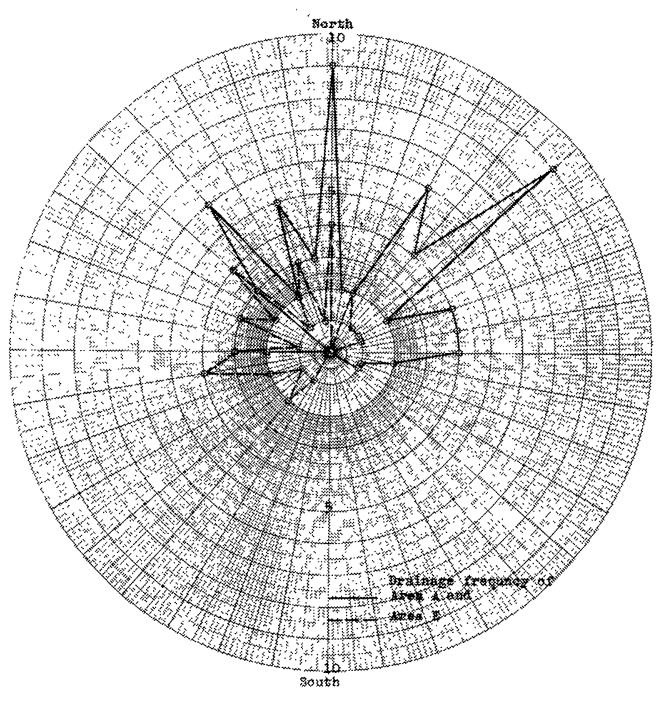

Fig. 5 Drainage frequency diagram. Pattern in area $\mathrm{A}$ and $\mathrm{E}$. Drainages plotted at $10^{\circ}$ intervals. Radius of diagram eqvals 10 drainages. $\mathrm{A}$ 队び $\mathrm{B}$ 地区の水系の数。

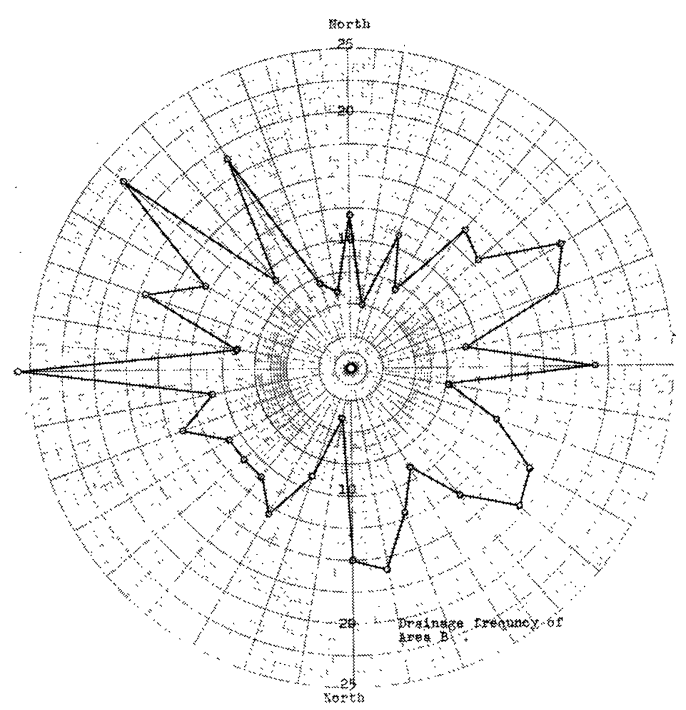

Fig. 6 Drainage frequency diagram. Pattern in area B. Drainages plotted at $10^{\circ}$ intervals. Radius of diagram equali 25 drainages. $\mathrm{B}$ 地区の水系の数。

C 地区：比較的直線状に伸びる水系がポプラ樹枝状 に発達する。

D地区：全般的にC 地区に近いが B 地区状の水系も まじえている。

E地区：A地区と同様。

$\mathrm{F}$ 地区：発達状態はB 地区に類似するが面積が狭少 ななめ全体的なパターンは明らかになしえ ない。

2） Table 2 から密度および頻度は，C 抢よび D 地

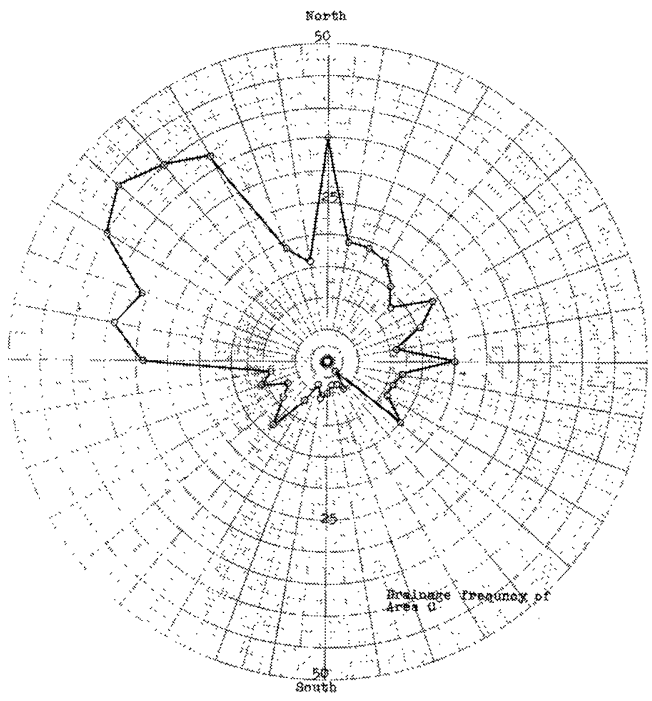

Fig. 7 Drainage frequency diagram. Pattern in area C. Drainages ploited at $10^{\circ}$ inte rvals. Radius of diagram exuals 50 drainages. C地区の水系の数。

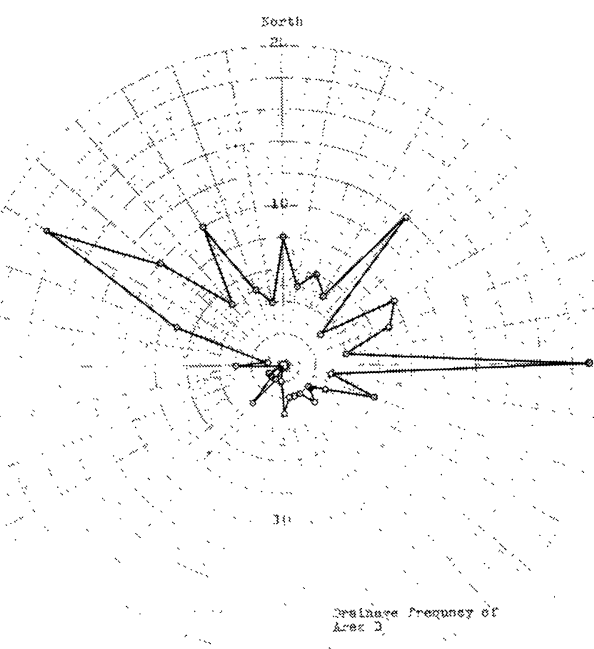

sis

Fig. 8 Drainage frequency diagram. Pattern in area D. Drainages plotted at $10^{\circ}$ intervals. Radius of diagram equals 20 drainages. $\mathrm{D}$ 地地区の水系の数。

区， $\mathrm{F}$ 地区， B 地区 $\mathrm{A}$ および $\mathrm{E}$ 地区の順に低く なる。

3） Fig. 3, Fig. 4 から A, d 地区では密度, 頻度と もに非常に低く， B，F 地区ではやや高くなるが， いずれも高低の差が少なくほぼ均等である。一方, C, D 地区では，高低の差が著るしく，高い部分と 低い部分がほぼ南北方向に連らなっている。

4） Fig. 5 Fig. 8 から水系の方向はそれぞれつぎの 方向に発達している。 


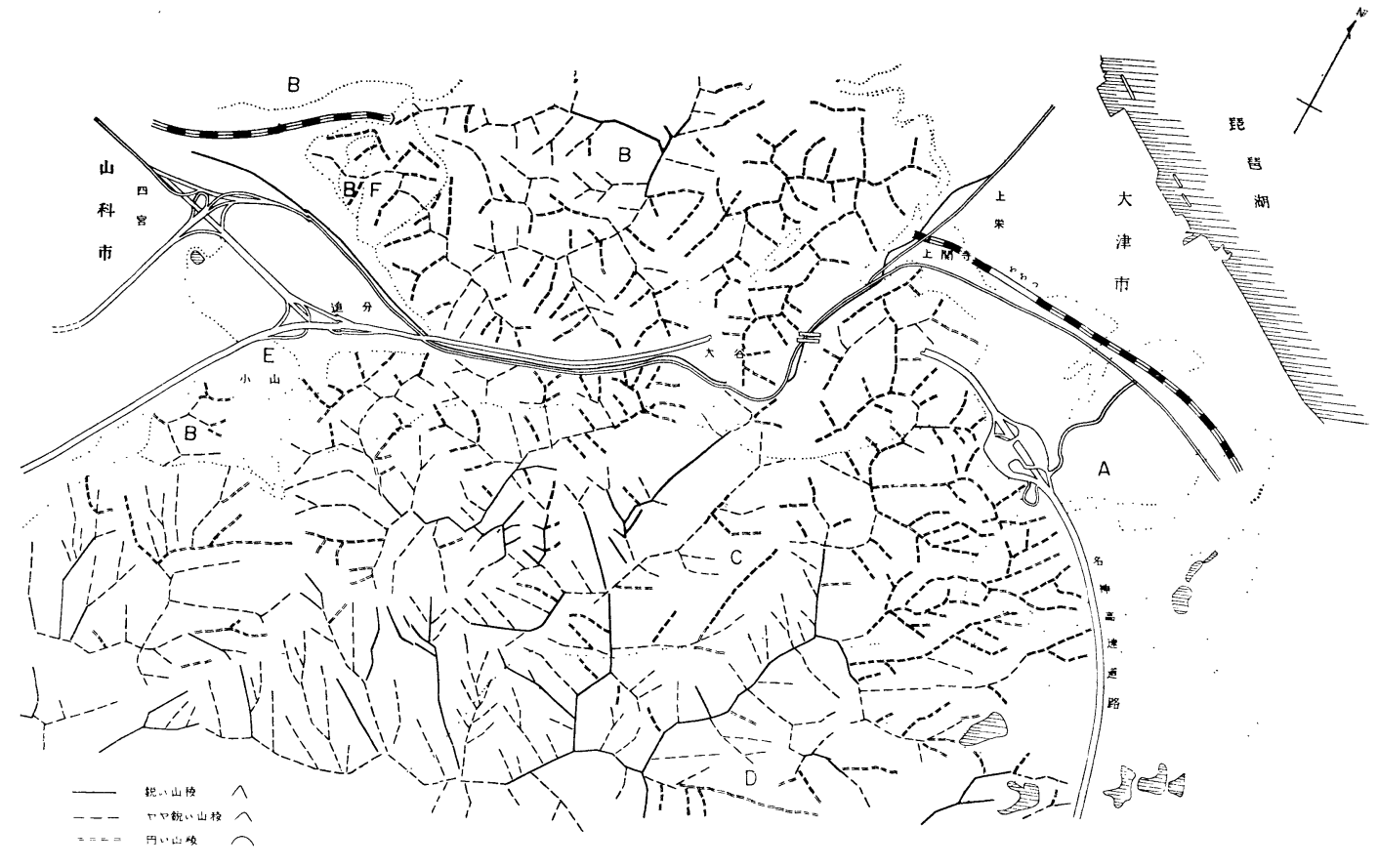

SCAL $\quad 1: 15,214$

Fig. 9 Map of ridge shape in Osakayama area.

A地区 : NS $\sim \mathrm{N} 20^{\circ} \mathrm{W}, \mathrm{N} 30^{\circ} \mathrm{E} \sim \mathrm{N} 50^{\circ} \mathrm{E}, \quad \mathrm{N} 70^{\circ} \mathrm{E} \sim$ $\mathrm{N} 80^{\circ} \mathrm{W}, \mathrm{N} 40^{\circ} \mathrm{W} \sim \mathrm{N} 50^{\circ} \mathrm{W}$

$\mathrm{B}$ 地区 : $\mathrm{NS} \sim \mathrm{N} 10^{\circ} \mathrm{W}, \mathrm{N} 30^{\circ} \mathrm{E} \sim \mathrm{N} 70^{\circ} \mathrm{E}, \mathrm{N} 80^{\circ} \mathrm{E} \sim$ $\mathrm{EW}, \mathrm{N} 30^{\circ} \mathrm{W} \sim \mathrm{N} 60^{\circ} \mathrm{W}$

C地区: $\mathrm{N} 5^{\circ} \mathrm{E} \sim \mathrm{N} 20^{\circ} \mathrm{E}, \quad \mathrm{N} 40^{\circ} \mathrm{E} \sim \mathrm{N} 50^{\circ} \mathrm{E}, \mathrm{EW} \sim$ $\mathrm{N} 70^{\circ} \mathrm{W}, \mathrm{N} 30^{\circ} \mathrm{W} \sim \mathrm{N} 60^{\circ} \mathrm{W}$

D地区: NS, $\quad \mathrm{N} 40^{\circ} \mathrm{E} \sim \mathrm{N} 70 \mathrm{E}, \mathrm{EW} \sim \mathrm{N} 70^{\circ} \mathrm{W}$, $\mathrm{N} 30^{\circ} \mathrm{W} \sim \mathrm{N} 60^{\circ} \mathrm{W}$

E地区: NS $\sim 20^{\circ} \mathrm{W}, \mathrm{N} 20^{\circ} \mathrm{E} \sim \mathrm{N} 40^{\circ} \mathrm{E}, \mathrm{N} 70 \mathrm{E} \sim$ $\mathrm{EW}, \mathrm{N} 50^{\circ} \mathrm{W} \sim \mathrm{N} 70^{\circ} \mathrm{W}$

5）谷の形状および谷底堆積物を判読するとAおよび E地区では広く浅い下降谷で細粒な粘土，砂，礫が 厚く堆積している。B地区では，狭くやや浅いF降 谷が発達し比較的細粒な岩屑が堆積する。これらの 水系には適従谷が多い。CおよびD地区では狄く深
い平衡谷が発達し，多くの岩底には，粗椟な岩屏， 砂砅からなる厚い堆積物が埋積する。全般的に必然 谷が多いがD地区にはしばしば適㹬谷が見られる。 F 地区では比較的広く浅いF F降谷が発達し粗粒な岩 屑が谷底をうめている。

6）以上の判読結果を基として，各地区の岩層をつぎ の様に解釈した。

A地区：未固結な粘土質な地層を主体とする堆積物 が分布する。

B 地区：比較硬質ではあるが，南北力向の弱線が発 達しやや風化・崩壊しやすい岩石が分布す る。

C地区 : 頁岩, 砂岩等の侵蝕作用に比較的弱い堆積 岩が互層する。

$\mathrm{D}$ 地区：C 地区と同様であるが一部E地区の岩層 を挾在す る。

E地区：A地区と 同様の堆 積物が分 布する。

$\mathrm{F}$ 地区：風化・崩 壊した併 入火成岩 からなる

Table 3 Classification of ridges. 山稜型熊の分類とその道さ。 


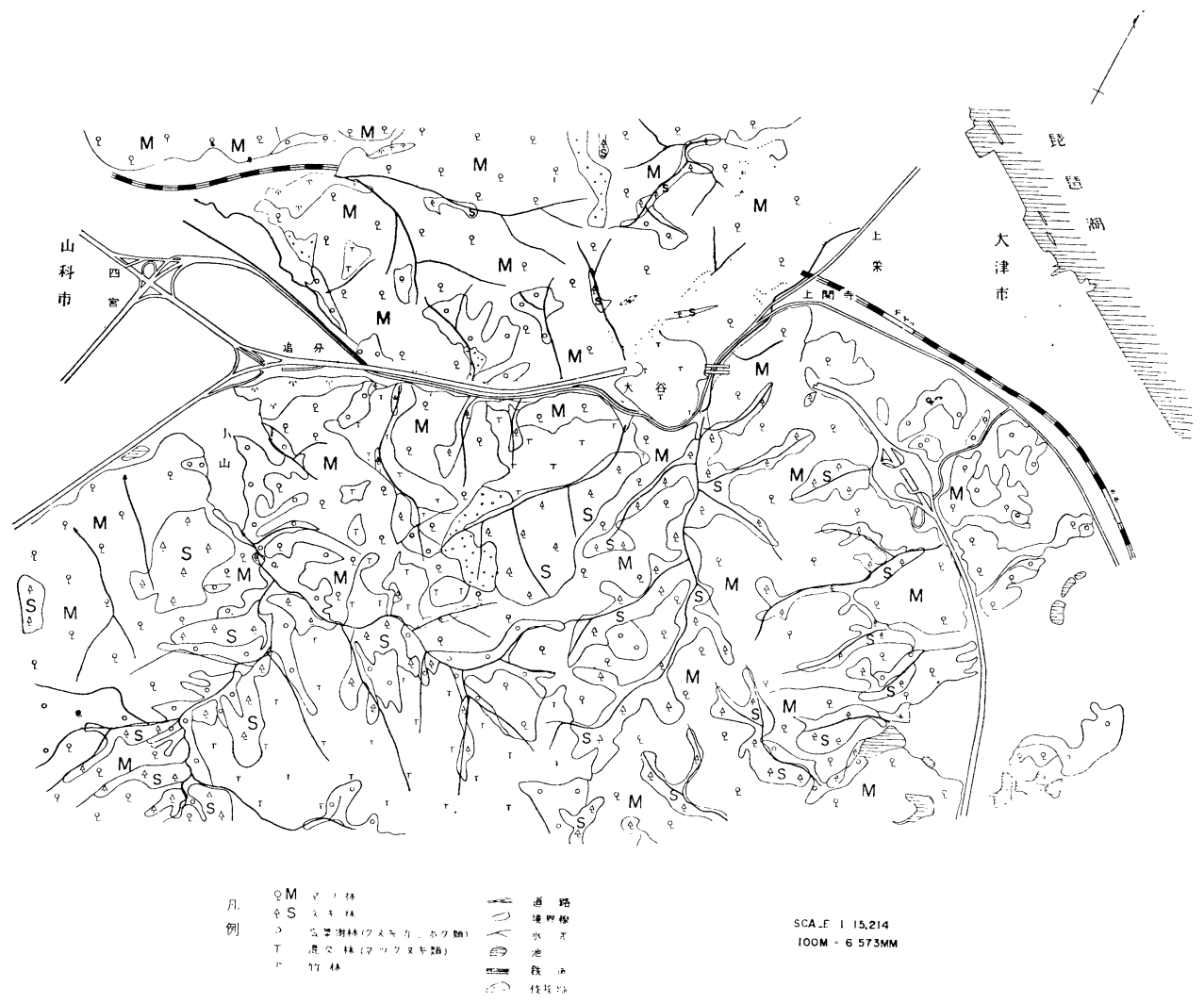

Fig. 10 Map of vegetation in Osakayama area.

II-1-2 山形 (Mountain shape) の判読

全般的な形状，形態とくに侵蝕，風化の状態，抵抗 性等を考察するため山稜，山腹斜面の判読を行なっ た。主観的ではあるが，山稜を鋭いもの，円いもの， その中間のものの 3 つに分し，Fig. 9 を作成し，さ らに Table 3 でこれるを定量的に解析した。

以上の判読の結果に全般的な地形判読の結果も加え て以下の様な解积を行なった。

1） $\mathrm{A}$ 抢よび $\mathrm{E}$ 地区は，ともに起伏の少ない丘陵性 山地からなり平坦な低い山稜, 緩い四型斜面が発達 する。B地区では比聆的円い山稜が東西抢よび南北 方向に延びやや急な叫斜面が発達する。Cおよび D 地区では鋭く高い山稜，急峻な平衡㻌面が発達し， ばしば東西方向に延びるケスタ状の地形を呈する。

F 地区は円い山稜の残丘状地形を示す。

2) A地区、ほ添水平に横たわる第四紀洪積世の堆積

E地区 物。

B地区：均質硬質な岩石 で構成され風化 がいちじるしい

C地区 東西方向の一般 お地区 走向を有し北に
急傾斜する比較的侵蝕作用に弱い岩層が 互層する。

$\mathrm{F}$ 地区：風化が著るしい花崗岩質併入岩からなる

\section{II-2 植生, 土壤 (Vegetation and Soil) の判読}

植生の種類, 密度, 分布状態, きめ, 色調などを定 性的にあるいは定量的に判読, 解析し土㙵, 岩質を判 定する゚ Fig. 10 に示した植生の判読図をみると全般 的に人工植林地が多いが，その植生の分布には各地区 でつぎのような特徴が見られる。

A, E地区：均質で良質なマツ，スギ，七ノキ類を主 体としタケが多い。これらの生育状態は非 常に良好で厚い肥沃な水積土が分布する。

B地区：マツおよび広葉樹林が大半を占め, これら の生育状態はあまりょくない。全般的に肥 沃度の低い珪酸質な残積土, 粗粒な運積土,

\begin{tabular}{c|c|c|c|c|}
\hline Area & Number of samples & Total of measured value & Mean & Standard deviation \\
\hline B & 14 & 3.32 & 0.24 & 0.06 \\
\hline C & 22 & 4.51 & 0.21 & 0.05 \\
\hline D & 5 & 0.95 & 0.19 & 0.04 \\
\hline
\end{tabular}

Table 4 Density of photographic tone. (Measured by a photodensitometer) 包鬧の測定澧度。 
とくに崩積土が分布する。

$\mathrm{C}, \mathrm{D}$ 地区 : 全般的にきめの荒いマッの純広葉樹との 混交林が大半を占めるが，谷底部周辺では 良質なスギ，ヒノキの分布が多い。

全般的に比較的細粒，比較的，肥沃な残 積土，運積土が発達している。

F 地区：マッの純林が分布し，粗粒，肥沃度の低い 酸性な残積土が発達している。

\section{II-3 色調，きめ（Tone and Texture）の判読}

航空写真上で巨視的にみる色調の違いからは土堙お よび構成岩石の違いを，さらに植生土壤上に現われた 線状の色調の違いから地質構造上の弱線を，またきめ の違いから岩石の風化，崩壊の状態などを判読する。

各地区ともそのきめに大差はないが，B地区にやや 荒れ肌の所が多く，またF地区ではかなり荒く比較的 風化崩壊しやすい岩石が分布する。

色調は肉眼で判定すると $\mathrm{A}, \mathrm{E}$ 地区においてもっと も暗く， B 地区， C, D 地区, F 地区の順に明るくなる。 つぎに B, C, D 地区にみられる南斜面の草地約 40 地 点を選んでコダック社製濃度計でその濃度を测定しそ の結果を Table 4 に示した。肉眼抢よび計測によっ ても B，C，D地区では大差がないが， A，E地区抢よ びF地区は肉眼で容易に区別することができる。

\section{II4 Photogeological lindament $の$ 判読}

今までわれわれは航空写真上にみられる地質学的要

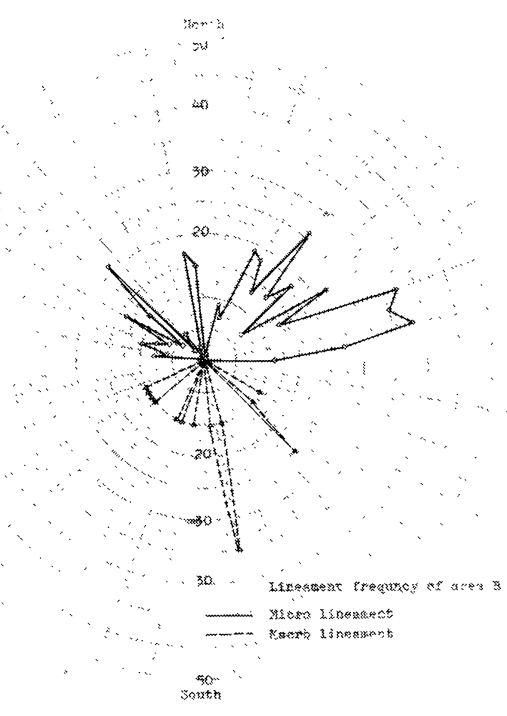

Fig. 12 Lineament frequency diagram. Pattern in area B. Lineaments plotted at $5^{\circ}$ intervals. Raeius of diagram equals 50 lineaments. B 地区の lineament の方位別頻度。

因によって形成された線状の形象を現わす用語として 漸定的に lineament を用いてきた。しかしながら， lineament の定義はいまだ諸外国でも一定せずさらに 人によっては種及様々の用語が用いられているし，わ が国に拉てもまちまちで，現在これらをあらたに定 義分類しなおす必要が生じてきている。しかしながら ここでは，航空写真上にみられる線状の形象を漸定的 につぎのように分類，定義しなおして用い，なおくわ

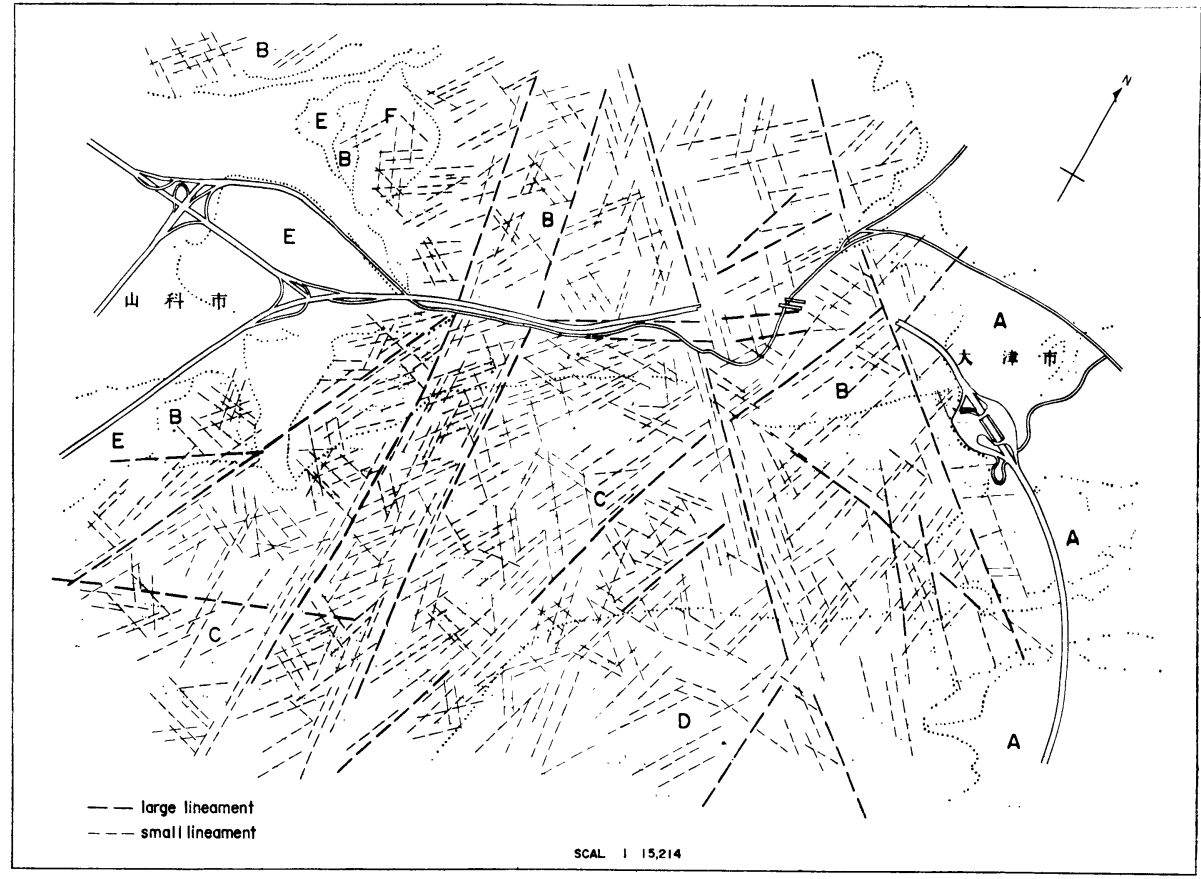

Fig. 11 Map of photogeological lineaments in Osakayama area. 


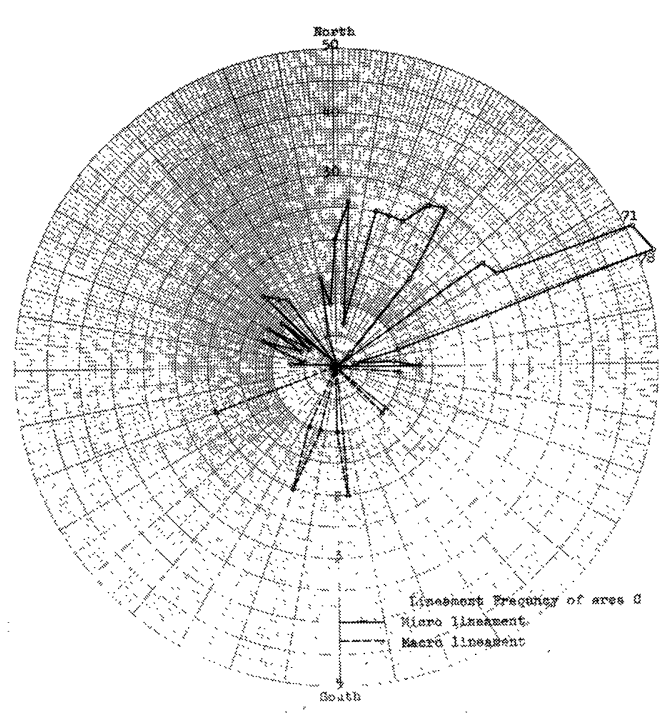

Fig. 13 Lineament frequency diagram. Pattern in area C. Lineaments plotted at $5^{\circ}$ intervals. Radius of diagram equals 50 lineaments. C 地区の lineament の方位别頻度。

しくはつぎの研究の課題としたい。

航空写真上に現われている線状の形象をその成因に より分類して，地質学的要因により生じたものを（1）

Photogeological lineament, その他の要因により生じ たものを（2） Noephotogeological lineamentとよふ。 Photogeological lineament は地形（水系を含む）, 植 生, 土㙥, 岩石の露頭上に現われ, 断層, 破砕带, 節 理などの地質学的断裂系と, その他の層理, 地層の境 界などの岩層中における一次的構造を示すものであ

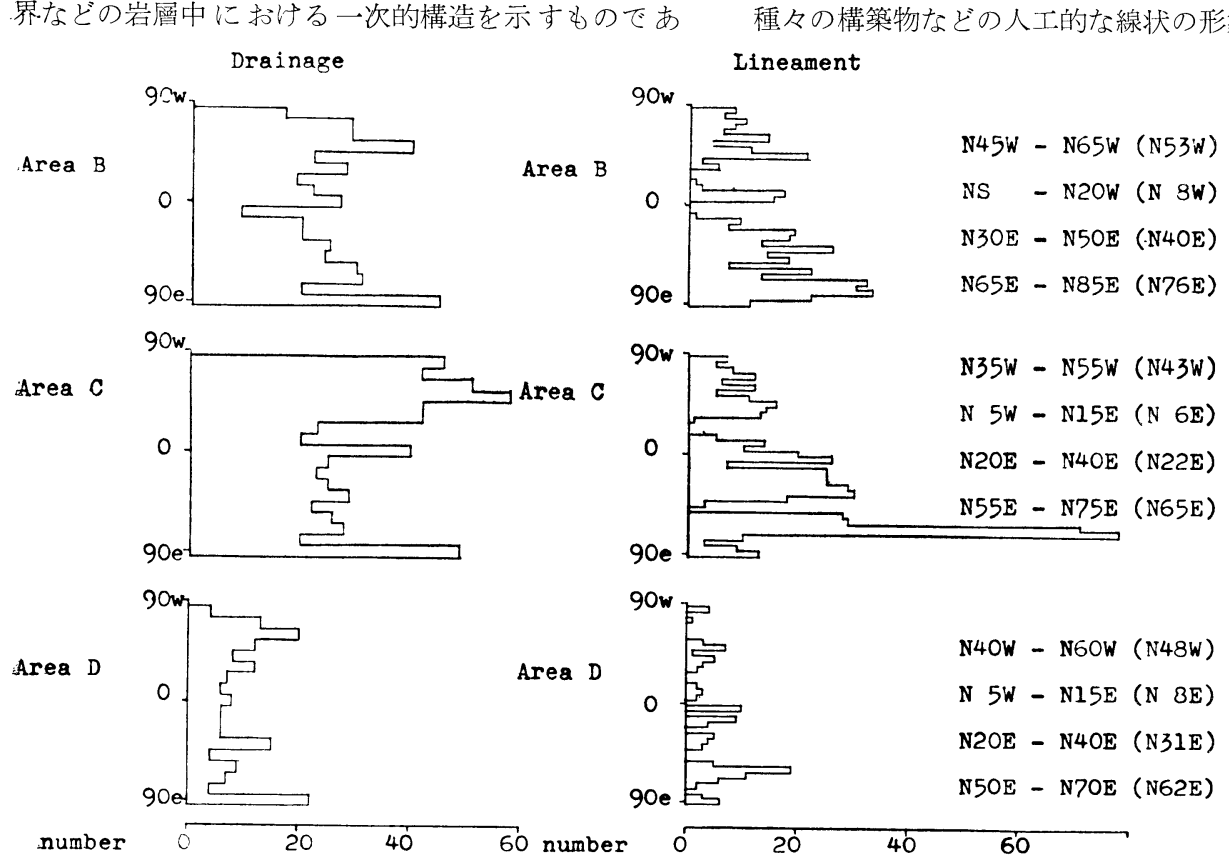

Fig. 15. Comparison of drainage and photogeological lineoment. 水素の方位別類度と lineament の方位別頻度の対比。

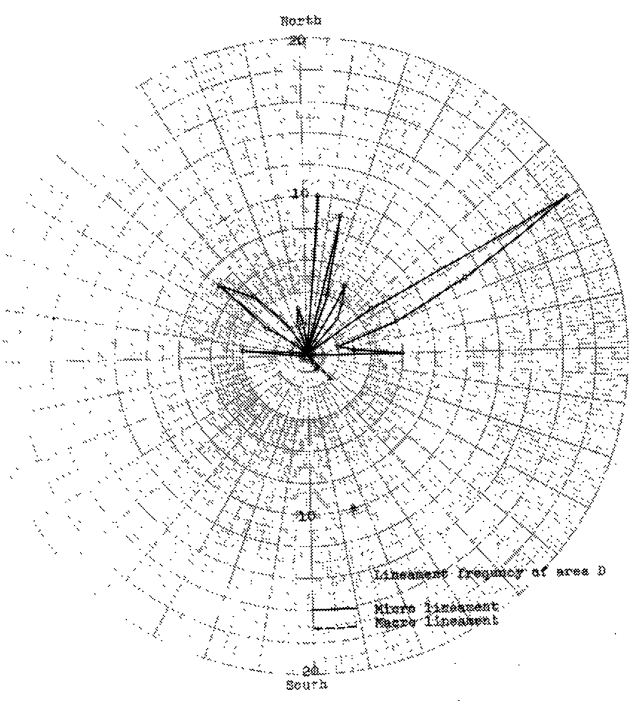

Fig. 14 Lineament frequency diagram. Pattern in area D. Lineaments plotted at $5^{\circ}$ intervals. Radius of diagram equals 20 lineaments. D地区の lineament の方位别頻度。

る。さらにこれを Lattman, 1958 の分類に従いその 規模から長さ $1500 \mathrm{~m}$ 末満の小規模な, 主として小断 裂系, 層理, 地層の境界を示す妇のを Micro photogeological lineament, 長さ $1500 \mathrm{~m}$ 以上の大規模な, 主として大断裂系を示すものを Macro photogeological lineament とよふ。 Nonphotogical lineament は卓越 風, 氷河作用などの自然現象によって生じた線状の形 象, 陰影による線状の形象および伐採, 植林, その他

種々の構築物などの人工的な線状の形象をいう。 
Photogeological lineament の判読から地質および地 質構造を解析する方法は，これらを短期間にまた連続 的に追跡することができ，さらに地上の露頭ではみい だしえないものの存在を明らかにし得るなどの点で非 常に有用であるが，またその判定にあやまちをおかし やすい欠点もある。したが上て現段階での lineamentの 判読では豊富な経験と資料が必要であり。さらに必要 個所の現地での点検が必要となる。

Fig. 11 に示した Photogeological lineament から岩 層および地質構造を解析した。またその方向と数を Fig. 12，13，14 のダイヤグラムに示し，さらに Fig. 15 のヒストグラムで水系との関連性を考察した。

1）AおよびE地区をのぞき，全般的に Photogeological lineament がよく発達している。

ここにみられる Macro photogeological lineament は殆んど断層線谷, 断層線崖, ケルンコル, ケルン バットなどの線状配列として地形的に判読された大 断裂系でこれに平行する Micro photogeological lineament を伴ない $3500 \mathrm{~m}$ 以上連続して表われて いる。Micro photogeological lineament は主として 植生，土壤上で判読された小断裂系执よび層理，地 層の境界で Macro photogeological lineament を境 いとしてその発達状態は異なり，また各地で異なる。

2) Macro photogeological lineaments $は \mathrm{NS} \sim \mathrm{N} 15 \mathrm{~W}$, $\mathrm{N} 20^{\circ} \mathrm{E} \sim \mathrm{N} 30^{\circ} \mathrm{E}, \mathrm{N} 80^{\circ} \mathrm{E} \sim \mathrm{N} 80^{\circ} \mathrm{W}, \mathrm{N} 40^{\circ} \mathrm{W} \sim \mathrm{N} 60^{\circ}$ W の 4 系統に分類される。

Micro photogeological lineamentはFig. 15 に示 した通り。
B地区ではほぼ $\mathrm{N} 10^{\circ} \mathrm{W}, \mathrm{N} 40^{\circ} \mathrm{E}, \mathrm{N} 75^{\circ} \mathrm{E}, \mathrm{N} 55^{\circ} \mathrm{W}$ C地区ではほぼ $\mathrm{N} 5^{\circ} \mathrm{E}, \mathrm{N} 20^{\circ} \mathrm{E}, \mathrm{N} 65^{\circ} \mathrm{E}, \mathrm{N} 45^{\circ} \mathrm{W}$ D地区ではほぼ $\mathrm{N} 14^{\circ} \mathrm{E}, \mathrm{N} 30^{\circ} \mathrm{E}, \mathrm{N} 60^{\circ} \mathrm{E}, \mathrm{N} 50^{\circ} \mathrm{W}$ の 4 万向が卓越している。また $\mathrm{B}, \mathrm{C}, \mathrm{D}$ の各地区 を通じて $\mathrm{N} 60^{\circ} \mathrm{E} \sim \mathrm{EW}$ 万向の Micro phtogeological lineamenł は層理あるいは地層の境界を示すもので あり，その傾斜はほぼ $60^{\circ} \mathrm{N} \sim 90^{\circ} \mathrm{N}$ で比較的北に 急傾していることを示している。

3) Macro photogeological lineament として判読され た南北性の大断裂系は，東西性のものに比べて現地 形により強く影響を及浪していることからみて，南 北性の断裂系は東西性のものに比べてより後期に形 成されたものと判定される。

4) Photogeological lineament と水采の発達状態とを 比較すると，B地区の水系は断裂系に規制されると ころが大きいが，C 执よ゙ D 地区こは断裂系に規 制されるところが少なく，両地区の岩石が明らかに 異なることを示している。

\section{III 地啠および地質構造の判定}

前述の各素の判読・解析の結果と岩層の判定結果を 綜合的に考察し地質扩よび地質構造を判定した。その 結果, この地域は頁岩粘析岩, 砂岩, チャートなどの 堆積岩とこれを貫く火成岩抢よびこれらを不整合にお おう洪積世，沖積世の堆積物で構成され，東西性の占 期構造と南北性の新期構造に規制されている。

各要素の判読結果をまとめて Table 5 に示した。 さらに各要素の判読図抢よびその判定の結果を基にし

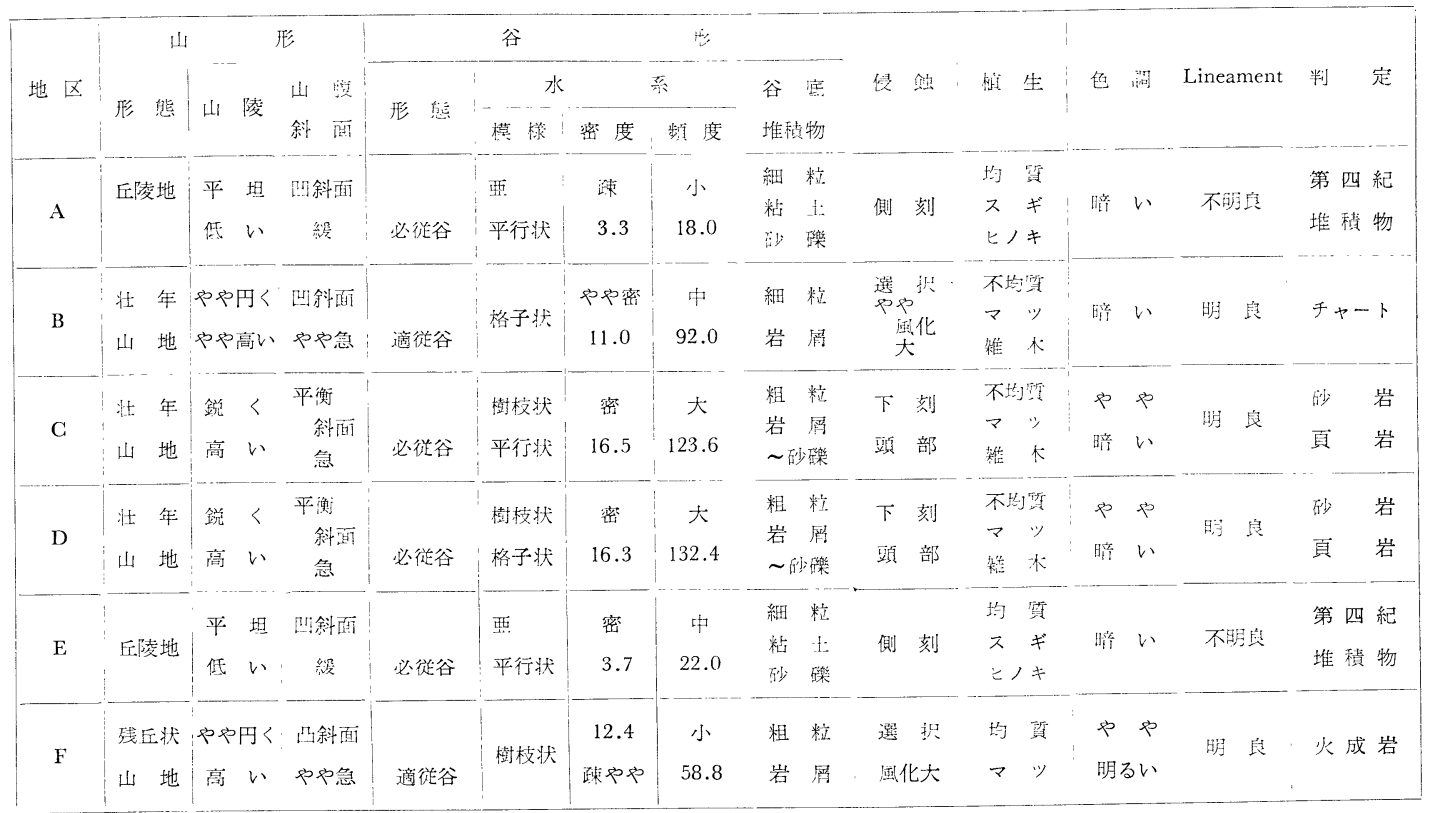

Table 5 A summary of the result of photogeological interpretation. 


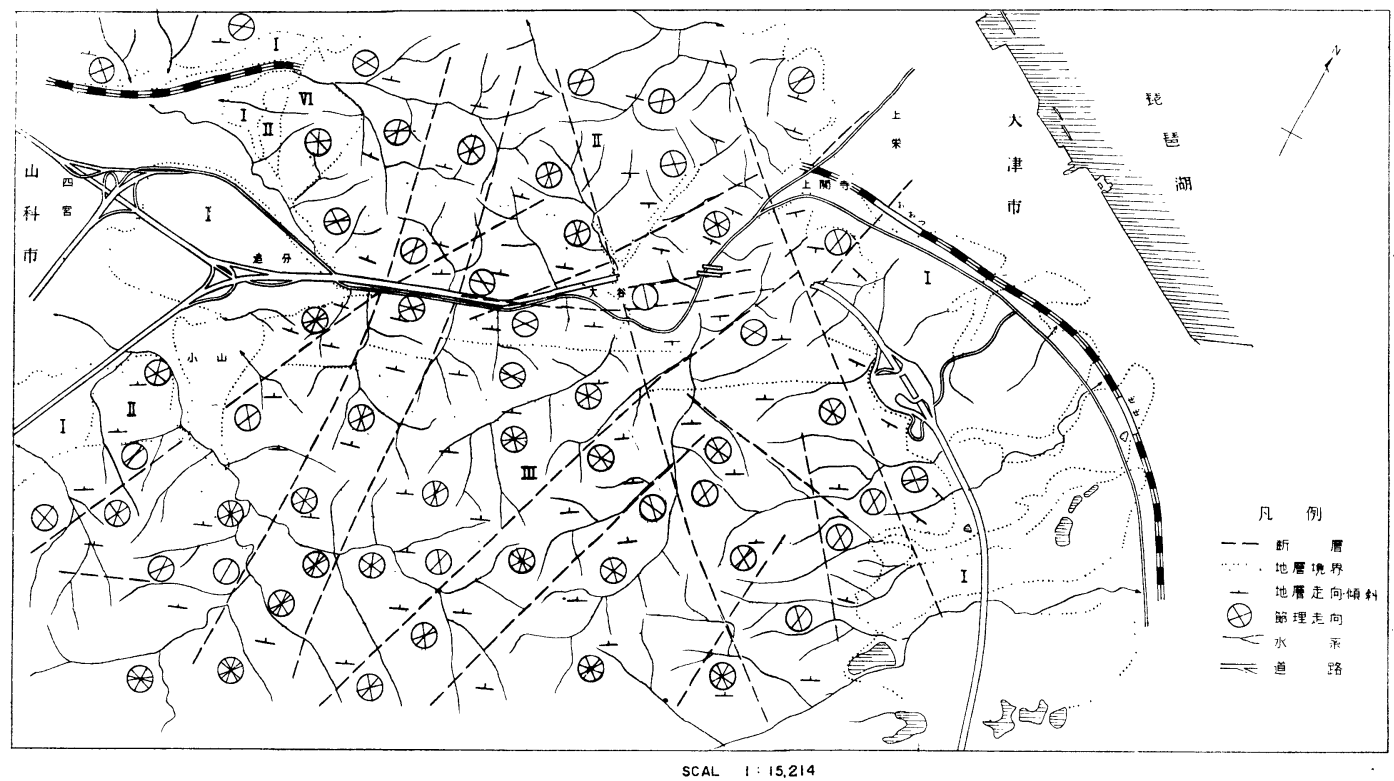

Fig. 16. Preliminary photogeological map of Osakayma area.

てこれに若干の既存の資料を加えFig. 16 に示した写 真地質学的予察図 (Preliminary photogeological map) を作成し判読結果を総括した。

Fig. 16 ではこの地域を 5 つに区分し, それぞれそ の岩層をつぎのように判定した。

I 地区：粘土，砂，礫からなる洪積層。

II地区：チャートを主体として頁岩，砂岩を挾在す る古生層。

III地区：頁岩, 砂岩, チォートの互層からなる古生 層。

IV地区：石英斑岩ないしは花崗斑岩。

$\mathrm{V}$ 地区, 冲積層。

古生層はほぼ東西方向の走向で北に急傾斜し，これ をおおい洪積層がほぼ水平に分布している。断層执よ び破砕带は東西ないしは一北東一南西性の古期構造と 南北ないしは北西一南東性の新期構造に大別され，い ずれも高角度で傾斜している。古生層中における節理 は全般的によく発達し，とくに東西方向の節理は層理 の走向と相まって広く地形に影響を及ぼしている。 さらに若干の

\section{現地調查の結果} を加え Fig. 17 の地質平面図沶 よび断面図を作 成した。その層 序をまとめると Table 6 のよう になる。

\section{ま亡め}

以上，写真地質学的判読の基礎的要素とその判読， 解析の概要及び判定結果についてのべてきたが，ここ では, その後, 現地で調査, 点検した結果と比較して 航空写真の写真地質学的な判読を考察する。

1）岩層, 地層の違いは, 地形, 植生などいずれの要 素にもかなり明膫に反映されている。冲積層, 洪積 層抢よび堆積岩中の火成岩併入岩体などは航空写真 上に最子特徵的に現われており，その境界は，航空 写真を判読することによって一谓正確に把握するこ とができる。しかしながら構成岩石が複雑で抢のお のの岩層が分布がいたって狭少な地域だは, それら の境界の多くは Micro lineament として航空写真上 に現われ，これらの境界をを正確に判定することは難 かしくなる。実際而地区に拈けるように岩石の構成 が非常に複雑でさらにおの打のの岩層の分布範囲が 狭少になると個々の岩層を判別することはできなく なる。またFig.16で岩層の境界としたものの中には 単に岩理を示すだけのものがかなり含まれていた。

\section{Alluuium Terrace and River deposits \\ Diluvium Lucustrine deposits \\ Osaka Group \\ Kobiwako Grgup}

Tectonic movement formed geotectonic lines of $\mathrm{N}-\mathrm{S}$ set.

Mesozoic Igneous Rocks Granite Porphyry, Quartz Porphyry.

Tecronic movement fgrmed geotectonic lines of $\mathrm{E}-\mathrm{W}$ set.

Upper

Palaeozoic Chichibu Palaeozoic Group Chert, Sheale, Clayslate, Sandstone.
Clay, Sand, Gravel.

Clay, Sand, Gravel, Lignite.

Table 6 The stratigraphical order of Osakayama area. 逢坂山地区地舅層表。 

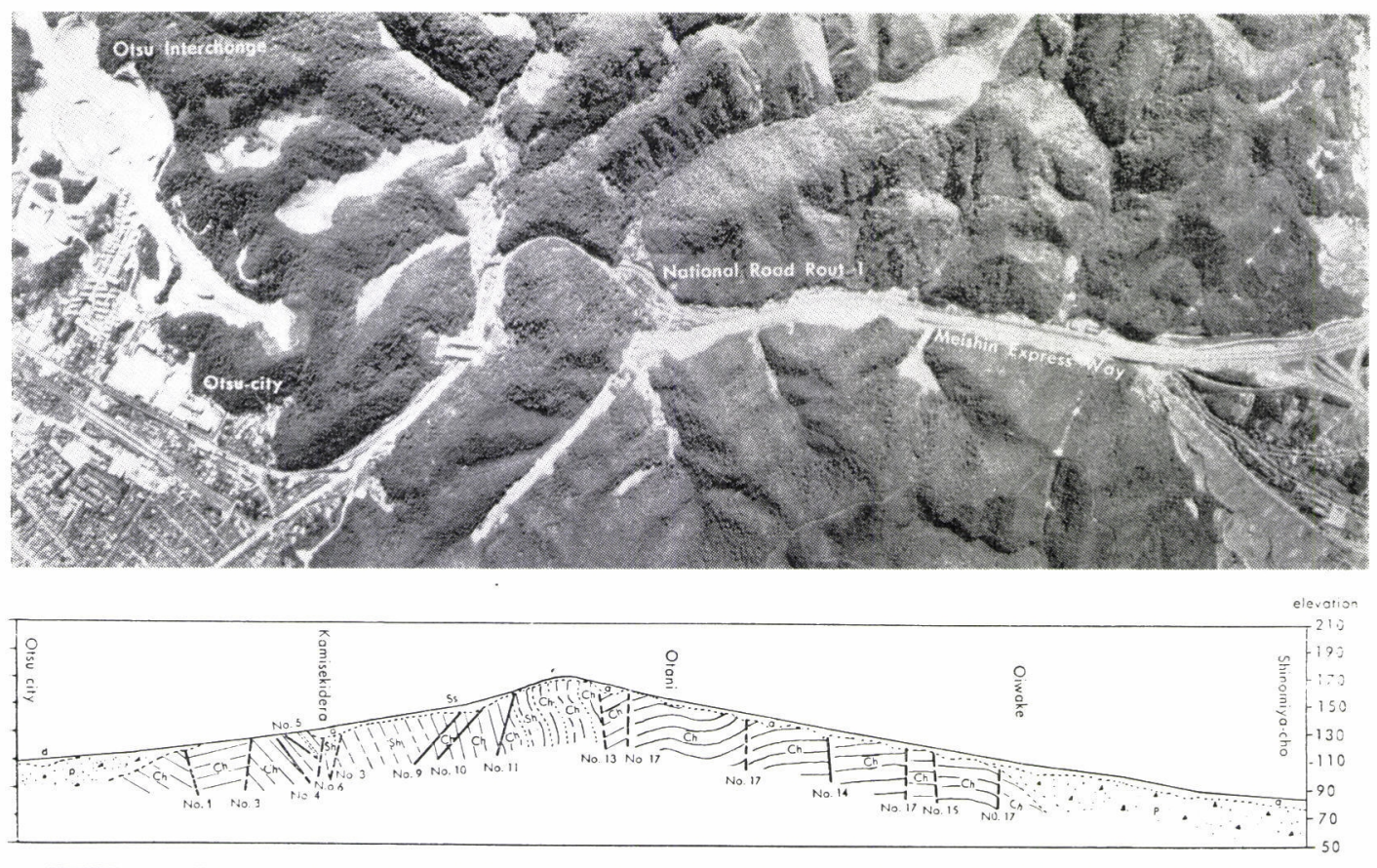

$\begin{array}{ccc}400 & 800 & 1200 \\ \text { geological propfile along national road route } 1 .\end{array}$

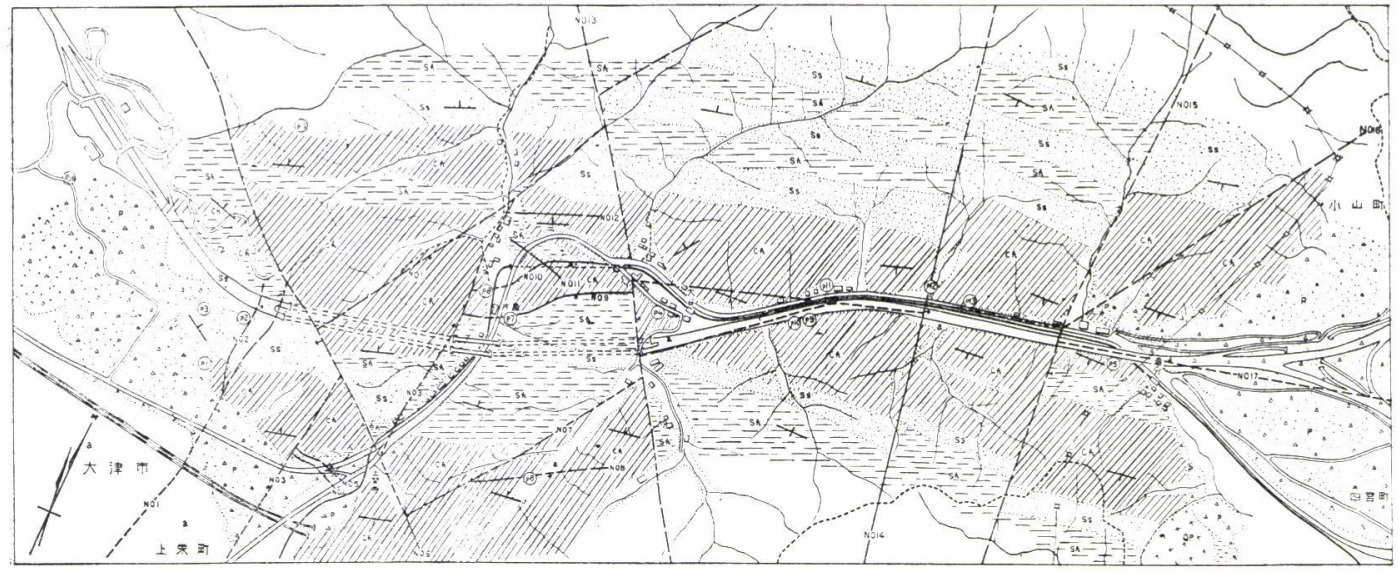

Geological sketck of Otsu-Yamashina area

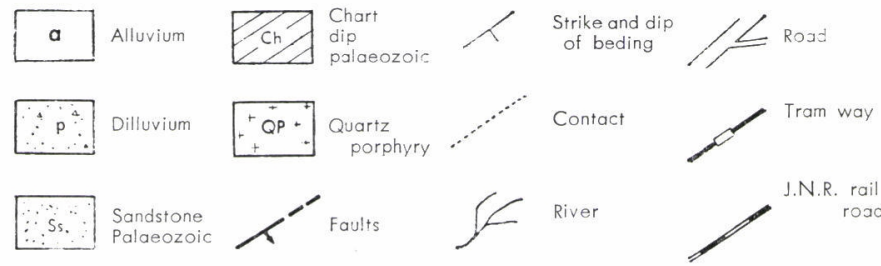

Fig. 17 Geological map of Osakayama area.

逢坂山地区の航空写真败び地質四。

ESh= $\begin{gathered}\text { Shale } \begin{array}{c}\text { or } \\ \text { Slate }\end{array} \text { Palaozoic } \\ \text { Prabale } \\ \text { faults }\end{gathered}$

:2）断層，破砕带などの大断裂系は，現地形に及ばす 影響も強く，岩層の判読結果も含めてこれらの走 向，傾斜抢よびその形成時期までかなり正確に把握
することができる。規模の小さい破砕带；節理など の小断裂系は主として植生, 土壤, 岩石の露頭上飞 判読されるが，大局的にその走向の方向が把握でき 
る程度でその傾斜まで測定することは難かしい。地 層の堆積状態およびその構造は，例えばケス夕地形 などのように広く地形に影響し，その走向，傾斜の 判定および測定は比較的容易に行なうことができ る。しかしながらここの地域の洪積層のようにほと んど水平に近い地層あるいは古生層のように非常に 急傾斜の地層ではその傾斜方向の判定にあやまちを おかしやすく，その測定精度孔著るしく低下する。

3）写真地質学的な判読要素の解析が写真地質学的な 調査の基礎であることはいうまでもない。したがっ て, 写真地質学の基磯的な研究の一貫として, これ らの各要素と地質および地質構造との相関関係を追 求することによってより科学的な判読を実施するこ とができ，写真地質学的な調査の限界をさらに拡大 することができる。また写真地質学的調査ではこれ らの各要素の科学的な判読と野外踏査によるチェッ クが充分に関連性をもって実施され，さらに地表地 質調査物理採査などの調査と緊密な連関性を保たせ ることによってより合理的に，より経済的に，汃 高い精度で調査を行なうことができよう。

\section{交献}

R. P. Nickelsen : "Photogeologic Fracture Trace
L. H. Lttman : Mapping in Appalachian Plateau." Bull. Amer. Assoc. Petrol. Geol. Vol. 42, No. 9 (1958)

L. H. Lattman: "Technique of Mapping Geologic Fracture Trace and Lineaments on Aerial Photographs.” Photo. Eng. Vol. 24i No. 4 (1958)

G. Henderson: "Air-Photo Lineaments in Mpanda
Area, Western Province, Tanganyica, Africa." Bull. A mer. Assoc. Petrol. Geol. Vol. 44, No. 1 (1960)

A. S. P. : "Manual of Photographic Interpretation" (1960)

D. R. Lueder : “Aerial Photographic Interpretation, Principles and Applications." McGraw-Hill, N.Y. (1959)

H. T. U. Smith : 'Aerial Photographic and Their Application." Appleton-Century-Crofts, Inc. N.Y. (1943)

V.C. Miller: "Photogeology.” McGraw Hill (1961) H. F. von Bandat: “Aerogeology" Gulf. P. C. (1962)

R. G. Richard: "Aerial Photographs in Geologic Interpretation and Mapping." U.S. G.S. Professional Paper 373 (1960)

西尾元充，吉田 登：“航空写真を利用した地質構 造の調査一大町トンネル付近を例にとって”土木 学会誌 第 74 号 (1961)

白石辰巳：“田麦山油田周辺地域の写真地質学的研 究” 岩石釷物鉱床学会誌 第 49 巻 第 1 号 (1963) 西尾元充，河原紀夫：“航空写真判読を利用した地 質調查，そのI一木曾上松町付近について一”日 本写真測量学会誌 第 1 巻 第 3 号 (1962)

西尾元充，河原紀夫：“航空写真判読を利用した地

質調查，その 2 一福島県梁川町立沢付近について -”日本写真测量学会誌 第 2 巻 第 2 号 (1963)

\begin{tabular}{|c|c|c|}
\hline 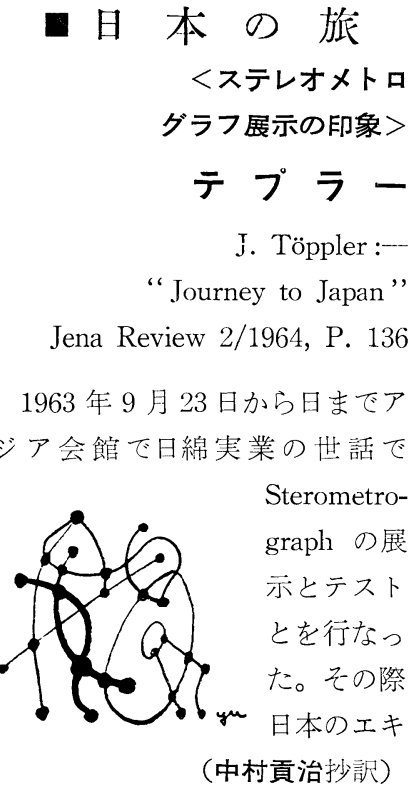 & $\begin{array}{l}\text { スパート } 170 \text { 名の示された関心に } \\
\text { 対しては感謝する次第である。 } \\
\text { 機械のテストは国際航業と東日 } \\
\text { 本航空とによって写真縮尺 } 1 / 15,- \\
000,1 / 10,000 \text { の } 15 \mathrm{~cm} / 23 \times 23 \mathrm{~cm}, \\
21 \mathrm{~cm} / 18 \times 18 \mathrm{~cm} \text { の空中写真を用 } \\
\text { いて行なわれ, 写真縮尺 } 1 / 10,000 \\
15 \mathrm{~cm} \text { の写真の場合高さの最大誤 } \\
\text { 差はであった。 } \\
\text { この機械はカバーされた設計 } \\
\text { だ, 標定諸元のハンドルも手近に } \\
\text { あって使い易く, 又コーヂネート } \\
\text { グラフへの電気的接続も好ましい } \\
\text { との評判であった。とくにテスト } \\
\text { を行なったオぺレータは } 5 \text { 倍の拡 } \\
\text { 大描画でのハンドルの作動は他の } \\
\text { 機械よりも軽いといっていた。 }\end{array}$ & 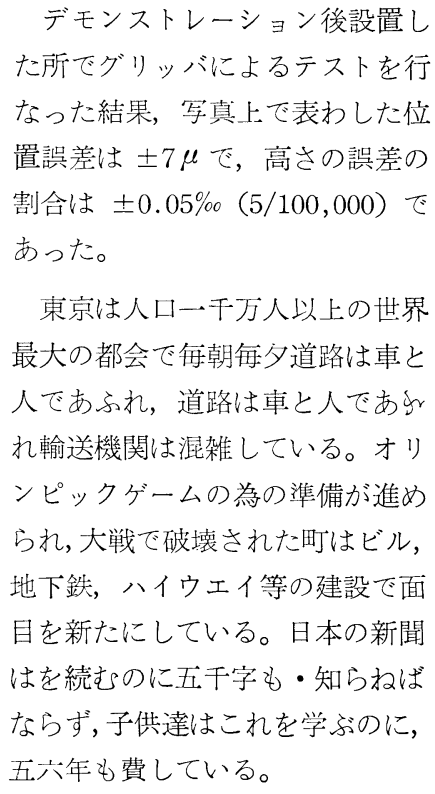 \\
\hline
\end{tabular}

